\title{
Василина Кравчук Техническая интеллигенция польского происхождения в Западной Сибири в начале XX в.
}

\section{$\mathrm{B}$} развитии Сибири начала XX в. немаловажную роль играли выходцы из разных стран, в том числе и из Польши, большинство которых оказалось здесь в результате ссылки. В 1877-1911 гг. в западных губерниях России ежегодно выносилось в среднем 300-350 приговоров по уголовным делам, связанных со ссылкой в Сибирь. В 1906-1909 гг. среди всех ссыльных в Сибири поляки составляли $34,9 \%{ }^{1}$.

Для них наш регион стал второй Родиной. Многие, поселившись в Сибири, оставили свой след в различных областях научнотехнического прогресса, даже в полных лишений условиях ссылки, занимая активную жизненную позицию. Среди таких людей можно назвать имя Антона Маньковского. Его отец Казимир Маньковский, варшавский дворянин, был сослан в Западную Сибирь как участник польского восстания 1863 г. Восстание, начавшееся в январе 1863 года в Польше и направленное «против социального и национального гнета российского самодержавия» ${ }^{2}$ было подавлено в 1864 г. Число репрессированных повстанцев, по официальным правительственным источникам, составляла около 18 тысяч человек. В общей сложности

\footnotetext{
${ }^{1}$ Историческая энциклопедия Сибири, т. 2, Новосибирск 2009, с. 644.

2 И. Никулина, Поляки - участники восстания 18632. на Алтае, [in:] Алтайский сборник, вып. 16, ред. В.А. Скубневский, Барнаул 1995, с. 95.
} 
на каторгу, поселение, в военную службу по суду, а также в административном порядке и под надзор властей до конца 1866 г. было сослано от 16 до 20 тысяч человек³. Вплоть до манифеста 1883 года, освободившего большинство повстанцев от наказания, Маньковский разделял незавидную участь ссыльных, бесправное положение и нелегкое существование в непривычно суровых сибирских условиях. «Поскольку его дети остались сибиряками, можно полагать, что Казимир не возвращался на родину, хотя там были обеспеченные родственники, к которым его сын Антон ездил в детстве и юности» ${ }^{4}$. Антон Маньковский родился предположительно в 1869 г. и «какую-то часть детства или юности провел в Польше, что наложило заметный отпечаток, по рассказам знавших его лично, на его манеры, стиль поведения, внешний вид» ${ }^{5}$. Антон, имея техническое образование, служил капитаном парохода «Дельфин», жил в Тюмени и в Томске.

Город Томск был основан в 1604 г. Уже в начале его существования там находится значительное число поляков, в основном военнопленных. Хотя в начале XX в. наряду с политической ссылкой существовал и ряд иных путей проникновения поляков в Сибирь: направление на военную, административную, религиозную службу, привлечение специалистов в связи с железнодорожным строительством и хозяйственным развитием региона, добровольное переселение крестьян на неосвоенные земли.

В рассматриваемый период поляки внесли заметный вклад во многие сферы жизни города, в том числе в архитектуру. Среди заметных архитекторов Томска польского происхождения можно назвать имена Алоиза Вакльницкого - городского архитектора, автора генеральных планов города, Константина Заранека - инженера-архитектора. В 1894 г. Заранек составил проект на пристройку двух боковых приделов в римско-католическом костеле. В период с июля по сентябрь 1903 г. исполнял обязанности городского архитектора. В 1902 г. был возведен в надворные советники. В Томске Заранек был директором местного отделения Императорского русского музыкального общества ${ }^{6}$.

${ }^{3}$ Историческая энщиклопедия Сибири, т. 2, с. 645.

4 М. Новоселова, Айсберг моей родословной, „Тальцы”, 2003, № 1 (17), с. 43.

5 Ibidem, c. 37-38.

${ }^{6}$ В. Богданова, Первые выпускники института гражданских инженеров в Томске, „Строительные ведомости” (Томск), 2005, № 3, с. 13. 
С 1902 по 1906 гг. Заранек преподавал в Томском технологическом институте рисование и архитектурное черчение.

Также нельзя не отметить имя Павла Нарановича - инженераархитектора, строителя Императорского Томского университета ${ }^{7}$. Уже в 1881 году под его руководством выкладывается весь фундамент и цокольный этаж под главный университетский корпус и под здание химического корпуса, отстраивается деревянный астрономический дом, устраивается водоснабжение из озера, проводятся дороги, завозятся строительные материалы. К осени 1885 года все основные постройки университета были завершены. К началу эксплуатации университета на территории учебного комплекса было построено более 20 зданий и технических сооружений. Университет имел автономное водоснабжение и газоосвещение.

Однако поляки не только строили и проектировали здания учебных заведений, но и преподавали там. Одним из основателей Томского технологического института, созданного 11 мая 1896 г. ${ }^{8}$, был Владимир Обручев, правнук ректора Варшавского университета, профессора Тымовского. Среди профессоров института поляков по происхождению можно назвать Янишевского, Соболевского, Рончевского и многих других ${ }^{9}$. Однако помимо вышеперечисленного поляки внесли заметный вклад в развитие и других сфер деятельности Томска. Среди томских специалистов можно выделить гидротехника Ивана Комодзинского, инженера путей сообщения Ипполита Клиновского и многих других.

Помимо Томска поляки, разумеется, жили и работали и в других областях региона, в том числе и на территории современного Алтайского края, расположенно на юго-востоке Западной Сибири. В начале XX в. территория нынешнего Алтая входила в состав Томской губернии. Горная промышленность, являвшаяся долгое время главной отраслью экономики округа, вступила после 1861 г. в полосу кризиса. С начала 70-х гг. стала неудержимо нарастать убыточность заводов, и к концу века почти все они были закрыты. На смену пришла частная промыш-

${ }^{7}$ Г. Скворцов, Участие поляков - томичей в формировании архитектурного образа Томска в период XVII-первой четверти XX веков, [in:] Сибирская полония: прошлое, настоящее, будущее, ред. В.А Ханевич, Томск 1999, с. 63.

${ }^{8}$ И. Лозовский, Н. Моисеенко, В. Офицеров, Польский след в Томском политехническом университете, [in:] Сибирская полония: прошлое, с. 141.

${ }^{9}$ Ibidem. 
ленность, которая, однако, существовала в своеобразных условиях, ибо развитие не только целых отраслей, но и отдельных предприятий строго контролировалось Кабинетом и местной администрацией.

В 60-е гг. XIX в. на территории Алтайского горного округа (включающего территории современного Алтайского края, Новосибирской, Кемеровской, Томской областей, Республики Алтай и Хакасии, Восточно-Казахстанской области Республики Казахстан) находилось немало поляков, 340 человек из них были ссыльными ${ }^{10}$.

В частности городским архитектором Барнаула был Иван Носович. Иван Каликст Носович родился 14 (27) октября 1862 г. в семье мелкопоместного дворянина в г. Ровно Волынской губернии. В 1889 г. он окончил Санкт-Петербургский императорский институт гражданских инженеров со званием инженера с правом на чин 10 класса и 17 февраля 1890 г. был назначен младшим архитектором строительного отделения при управлении приамурского генерал-губернатора.

В 1899 г. Носович принял предложение служить в Барнауле, в его формулярном списке значится должность техника по строительнодорожной части Алтайского округа ${ }^{11}$. По проектам Носовича были построены многие здания в Барнауле, Бийске а также ряд церквей в селах Алтая. Он экспериментировал и проектировал дома в разных архитектурных направлениях: в формах эклектики, модерна, неоготики, русского стиля ${ }^{12}$. Так, например, народный дом в городе Бийске, построенный в годы Первой мировой войны был возведен в формах эклектизма с элементами модерна ${ }^{13}$.

В начале XX в. Иван Носович был ведущим архитектором Алтая, внесшим огромный вклад в формирование архитектурного облика Барнаула ${ }^{14}$. Среди построек, автором которых является Носович - дом начальника Томского завода (1900), собственный дом архитектора (1907), Народный дом в Бийске и здание римско-католического

${ }^{10}$ И. Никулина, Политическая ссылка на Алтай в ХІХ в. (20-90-е г2.), [in:] Гуманитарному факультету-15 лет, Барнаул 2007, с. 58.

${ }^{11}$ Государственный архив Алтайского края (далее: ГААК), ф. 4, оп. 1, д. 145.

12 В. Скубневский, Поляки на Алтае (XIX-начало ХХ века), [in:] Польская интеллигенция в Сибири XIX-XX вв., Красноярск 2007, с. 72.

13 Idem, Вклад поляков в культуру, науку и медииину Алтая ХІХ-начала ХХ века, [in:] Европейские общины в российской провинции во второй половине XIX-начале XX в., ред. В.А. Скубневский, Барнаул 2010, с. 239.

14 В. Скубневский, С его именем связано..., „Культура Барнаула”, 2009, № 10. 
костела (1909) в Барнауле. Костел стал самой значительной постройкой мастера в Барнауле. В Государственном архиве Алтайского края хранится подписка И. Носовича от 1 августа 1909г. о «наблюдении за постройкою каменного здания Римско-Католической церкви (костела) в Барнауле» ${ }^{15}$. В 1912 г. Носович стал главным архитектором Барнаула. В 1913 г. в Петербурге было создано Русское общество городов-садов, в Барнауле появилось его отделение. Носович стал не только членом этого общества, но и разработал проект города-сада для северной части Барнаула ${ }^{16}$. И. Носович был и просвещенным общественным деятелем. С 1908 г. он являлся председателем Общества попечения о начальном образовании в Барнауле. Это общество немало сделало для народного просвещения, создавая бесплатные библиотеки и школы. Активным членом общества была и жена архитектора Ядвига. Барнаульский общественный деятель М. Курский писал о нем как о богатом «опытом и знаниями гуманном общественном деятеле, снискавшем симпатии и всеобщее уважение» ${ }^{17}$.

Носович работал главным архитектором Барнаула до 1 апреля 1919 г. По некоторым сведениям, в 1929 г. ему удалось выехать в Польшу, в Краков, дальнейшая его судьба не известна ${ }^{18}$.

По нашему мнению, к деятелям польского происхождения на Алтае можно отнести и Александра Адольфовича Лесневского. Он родился 23 августа 1866 г., был дворянином по происхождению, вероисповедание римско-католическое. Образование получил в Константиновском межевом институте, где по окончанию курса был выпущен со званием межевого инженера. В 1895 г. был откомандирован в распоряжение начальника Алтайского округа. Согласно формулярному списку, который хранится в Барнаульском архиве ${ }^{19}$, в 1896 г. он был назначен помощником заведующего межевыми работами в Алтайском округе и одновременно на него было возложено заведование типолитографией при Главном управлении Алтайского округа. С 1898 г. Александр Лесневский стал заведовать поземельно-устроительными работами и председательствовать в Барнаульской переселенческой комиссии.

${ }^{15}$ ГААК, ф. 69, оп. 1, д. 232, л. 12.

16 В. Скубневский, Вклад поляков в культуру, с. 240.

17 В. Петренко, Дом Носовича, „Алтайская правда”, 2001, № 322.

18 В. Скубневский, Вклад поляков в культуру, с. 240.

19 ГААК, ф. 4, оп. 1, д. 813. 
С 1906 г. Александр Лесневский стал заведующим чертежной Главного управления Алтайского округа и возведен в чин статского советника со старшинством. Он прослужил в этой должности и чине до 1913 г. 13 мая 1913 г. Лесневский был избран городским головой. На этом посту он принимал активное участие в благотворительной деятельности, следил за размещением военнопленных. В 1917 г. после национализации усадьбы, Александр Адольфович уехал в Новониколаевск, где и скончался от инфаркта 23 января 1920 г.

Резюмируя все вышеперечисленное, следует отметить, что поляки сыграли весьма заметную роль в различных областях науки и техники нашего региона, тем не менее, данная тема не вполне изучена, что обуславливает наши дальнейшие исследования этого вопроса.

\section{Polska inteligencja techniczna na zachodniej Syberii na początku XX w. (streszczenie)}

Niniejszy artykuł opisuje reprezentantów polskiej inteligencji technicznej, którzy działali na zachodniej Syberii w początkach XX w. Został opracowany na podstawie materiałów archiwalnych przechowywanych w Archiwum Państwowym Kraju Ałtajskiego, publikacji i badań. Jest próbą ukazania zróżnicowania aktywności polskiej inteligencji technicznej na zachodniej Syberii na początku XX w. Znaczna jego część została poświęcona administracyjnej, ekonomicznej, kulturalnej oraz oświatowej działalności Aleksandra Leśniewskiego, Iwana Nosowicza, Antoniego Mańkowskiego i innych - ich pracy zawodowej, udziału i roli w życiu publicznym regionu. Zaprezentowano także ich krótkie biografie, które powinny być interesujące dla polskich badaczy i czytelników.

\section{Polish technical intelligentsia in Western Siberia at the beginning of $20^{\text {th }}$ century (summary)}

The article discusses the host of representatives of Polish technical intelligentsia at the beginning of $20^{\text {th }}$ century in Western Siberia. Based on archival materials involving the State Archives of the Altay Region, reference books and researches. It's an attempt to show the diverse activities of Polish technical intelligentsia in Western Siberia at the beginning of $20^{\text {th }}$ century. Considerable space is devoted 
to issues of administrative and economic, cultural and educational activities of Alexander Lesnevsky, Ivan Nosovich, Anton Mankovsky and others, to their professional employment, participation and role in public life in the region, as well as drawing up their short biographies, which can be the interesting for Polish researchers and readers. 